\title{
SIKAP DAN MOTIVASI PRAMUWISATA BALI BERBAHASA KOREA TERHADAP WISATAWAN KOREA SELATAN KE BALI
}

\author{
Putu Yolanda Yuniari ${ }^{1}$, I Ketut Suwena ${ }^{2}$, I Gusti Putu Bagus Sasrawan Mananda ${ }^{3}$ \\ ${ }^{1}$ Email: yyuniari@gmail.com \\ Program Studi Industri Perjalanan Wisata, Fakultas Pariwisata, Universitas Udayana \\ 2Email: suwenaketut31@gmail.com \\ Program Studi Industri Perjalanan Wisata, Fakultas Pariwisata, Universitas Udayana \\ ${ }^{3}$ Email: gusmananda@unud.ac.id \\ Program Studi Industri Perjalanan Wisata, Fakultas Pariwisata, Universitas Udayana
}

\begin{abstract}
Bali has an attractive spot for South Korean tourists who are traveling to see their beautiful sceneries. Based on visitor statistics report as a result, the number of South Korean tourists has decreased significantly, and make an impact to tour guides in Bali. Tour guide becomes one of important profession to promote Bali as a tourist destination. The objectives of this research are to recognize a Korean tour guide's attitude towards South Korean tourists in Bali and the motivation that makes them survived in this industry. This research applies a qualitative descriptive analysis method with Likert scales. Its samples have chosen by purposive sampling with the amount of 100 tour guides in Bali. Data collection techniques are conducted using observation, questionnaires, interviews, literature studies, and documentation. The results of the research are divided into three indicators namely, cognitive, affective, conative and it shows from attitude variable, the indicator dominates with very agree statement is few of South Korea tourists who visit Bali with score 4.11. Meanwhile, in motivation variable are divided into two indicators namely pull and push factor. The results are tour guides becomes an activity to support their family is a pull factor and there is job opportunity become a tour guide is a push factor indicator.
\end{abstract}

\begin{abstract}
Abstrak: Bali merupakan daerah yang menarik bagi para wisatawan mancanegara seperti wisatawan dari Korea Selatan. Dilihat dari data statistik pad Bali Pusat Statistik di Bali bahwa salah satunya tahunnya mengalami kenaikan dan penurunan secara signifikan, yang merasakan dampak ini dirasakan oleh pramuwisata. Pramuwisata merupakan salah satu profesi yang penting dalam membantu untuk mempromosikan pariwisata kepada wisatawan Korea Selatan yang datang ke Bali. Tujuan penelitian ini untuk mengetahui sikap pramuwisata Bali berbahasa Korea terhadap kunjungan wisatawan Korea Selatan ke Bali dan untuk mengetahui motivasi pramuwisata berbahasa korea terhadap Wisatawan Korea Selatan yang berkunjung ke Bali. Penelitian ini menggunakan analisis deskriptif kualitatif dengan bantuan skala likert. Sampel ditentukan secara purposive sampling berjumlah 100 orang pramuwisata yang melakukan kegiatan kepemanduan di Bali. Teknik pengumpulan data dilakukan dengan observasi, kuesioner, wawancara, studi kepustakaan, dan dokumentasi. Hasil penelitian dibagi menjadi tiga indikator yaitu kognitif, afektif, dan konatif. Hasil menunjukkan bahwa pada variabel sikap, indikator yang mendominasi ialah wisatawan Korea Selatan yang berkunjung ke Bali dengan kategori tertinggi sangat setuju dengan skor 4.11. Sedangkan pada indikator pull factor dan push factor dapat dijelaskan bahwa, pada pull factor yang dominan ialah kegiatan kepemanduan ini untuk memenuhi kebutuhan keluarga, sedangkan pada indikator push factor yang dominan ialah adanya peluang kerja menjadi seorang guide.
\end{abstract}

Keywords: attitude; motivation; push and pull factor; tour guide. 


\section{PENDAHULUAN}

Definisi pariwisata dalam suatu perundang-undangan, yaitu UU No. 10 tahun 2009 tentang kepariwisataan, yang dimaksud dengan pariwisata adalah berbagai macam kegiatan wisata yang didukung oleh berbagai fasilitas serta layanan yang disediakan masyarakat, pengusaha, Pemerintah dan Pemerintah Daerah. Sesuai dengan definisi di atas, maka semakin meningkatnya jumlah wisatawan memerlukan adanya beragam fasilitas dan sarana pada tempat yang menjadi daerah wisata. Tentunya hal tersebut akan mendatangkan keuntungan dari pengeluaranpengeluaran wisatawan selama melakukan kegiatan kunjungan. Dimulai dari biaya pengeluaran transportasi, penginapan, makan dan minum, biaya daya tarik wisata, cindera mata, hingga biaya pemandu wisata jika diperlukan. Selain itu masih banyak keuntungan yang bisa didapatkan oleh tempattempat yang menjadi destinasi pariwisata.

Pulau Bali merupakan salah satu daerah tujuan wisata internasional yang sangat terkenal di dunia. Sektor kepariwisataan telah menjadi motor penggerak perekonomian dan pembangunan Bali sejak tahun 1970-an. Oleh karena itu, kepariwisataan menjadi bagian yang sangat erat dan tidak dapat dipisahkan lagi dalam kehidupan masyarakat dan pembangunan di Bali (Pitana, 2003). Perkembangan pariwisata di Bali kian pesat telah membuat Pulau Bali sebagai salah satu destinasi favorit bagi wisatawan nusantara maupun wisatawan mancanegara. Setiap tahunnya wisatawan yang mengunjungi Bali mengalami kenaikan maupun penurunan dan hal ini membuat beberapa instansi/perusahaan yang bergerak dibidang pariwisata salah satunya seperti tour and travel mengalami pasang surut kunjungan wisatawan mancanegara.

Data yang dihumpun BPS Provinsi Bali tahun 2019 menjabarkan kedatangan wisatawan mancanegara ke Bali. Dari data tersebut ada pula kunjungan wisatawan yang menurun walau tidak terlalu signifikan terutama pada tahun 2017 menuju 2018 yaitu kedatangan wisatawan asal Korea Selatan yang tiap tahunnya mengalami pasang surut. Jumlah kedatangan wisatawan Korea Selatan ke Bali seperti pada tahun 2017 sebanyak 161.765 orang menurun ke 143.581 orang ditahun 2018 atau mengalami penurunan sebesar $11,24 \%$ dengan presentase total tiap tahunnya yaitu $5,61 \%$ dan hal ini pula akan berdampak pada pelaku pariwisata terutama pramuwisata yang memang langsung berhubungan dengan wisatawan.

Keberadaan Bali sebagai salah satu destinasi wisata yang unggulan memungkinkan berbagai jenis wisatawan berkunjung ke Bali. Badan Pusat Statistik (BPS) Propinsi Bali menjabarkan bahwa wisatawan Korea Selatan yang datang ke Bali senang dengan negara tropis dan tentunya murah jika mata uang mereka Won ditukarkan dengan mata uang daerah tujuan seperti rupiah di Bali, Indonesia. Biaya yang murah itupun cukup untuk membayar akomodasi, makan, jasa tour, tiket pesawat dll. Hal ini pun menjadi nilai plus Bali sebagai destinasi yang ramah dikantong wisatawan asal Korea Selatan. Menyebarnya kesenian kontemporer Korea Selatan dalam tren "Korean Wave" bagi negeri asal Kimchi itu memang mendatangkan berkah tersendiri, khususnya bagi total pendapatan negara yang sedang beranjak menyaingi Jepang sebagai salah satu macan Asia yang disegani. Korea Selatan dinilai potensial untuk menyumbang lebih banyak wisatawan mancanegara ke Indonesia khusunya Bali yang memiliki kebudayaan yang khas dan hanya dimiliki oleh Bali. Direktur Sarana Promosi Pariwisata Kementerian Kebudayaan dan Pariwisata, Esthy Reko Astuti (2011), mengatakan wisatawan Korea Selatan itu memiliki karakter pasar dengan minat terutama pada produkproduk atau paket wisata honeymoon dan leisure yang sangat pas dengan segmen pasar Indonesia khususnya di Bali.

Namun diera digital ini banyak wisatawan nusantara maupun mancanegara lebih menyukai moda transportasi online atau bahkan menyewa kendaraan bermotor lalu pergi ke destinasi-destinasi tujuan menggunakan google maps atau waze untuk menunjukkan arah diperjalanan. Ini pun akan berdampak buruk, salah satunya pada pramuwisata berbahasa Korea itu sendiri yang mencari pendapatan lewat jasa guiding dan Pramuwisata ini pun hanya bekerja saat adanya panggilan atau diperlukan oleh tour and travel yang menaunginya, yang berdampak akan jarang bagi pramuwisata ini dapat melakukan kegiatan kepemanduannya. Disamping melakukan kegiatan kepemanduan, tak jarang pramuwisata memiliki kegiatan lain selain guiding seperti berdagang yang akan 
meningkatkan perekonomian pramuwisata itu sendiri disaat terjadi penurunan jumlah kunjungan wisatawan mancanegara, salah satunya wisatawan Korea Selatan yang menggunakan jasa tour and travel yang tercatat tiap tahunnya mengalami fluktuasi.

Diambil dari data DPD Himpunan Pramuwisata Indonesia Bali (2017) jumlah pramuwisata berbahasa Korea di Bali yaitu sebanyak 603 orang. Pramuwisata yang berbahasa Korea di Bali cukup banyak dan pastinya akan bertambah setiap tahunnya karena HPI Bali sendiri merekrut pramuwisata dari masing-masing divisi bahasa secara berkala yaitu merekrut pramuwisata setiap tahunnya. Banyaknya pramuwisata yang terdaftar sebagai anggota HPI Bali seperti yang dijabarkan oleh Ketua HPI Bali hingga pertengahan tahun 2018 yaitu I Nyoman Nuarta sebesar 80 persen dari total keseluruhan pramuwisata yang sudah terdaftar dan memiliki lisensi untuk melakukan kepemanduan baik sebagai pramuwisata lepas atau pramuwisata yang bernanung pada tour and travel, pada saat terjadinya penurunan jumlah wisatawan tersebut mengakibatkan pramuwisata jarang melakukan kegiatan kepemanduan.

\section{METODE}

Pengumpulan data dilakukan di 5 daya tarik wisata di Bali yaitu wisata (1) Pura Taman Ayun, Kabupaten Badung, (2) Pasar Seni Ubud, Kabupaten Gianyar, (3) Penglipuran Village Kabupaten Bangli, (4) Tanah Lot Temple Kabupaten Tabanan, dan (5) Tirta Gangga Kabupaten Karangasem. Dilaksanakan pada tahun 2019. Dipilihnya Kabupaten-Kabupaten ini sebagai objek penelitian dilihat dari segi kondisi daerah yang sudah berkembang yang memiliki prospek yang bagus dalam pariwisata baik di daerah tersebut maupun di Provinsi Bali, serta Kabupaten-Kabupaten ini merupakan daerah dimana pramuwisata bekerja pada umumnya, disamping itu banyak paket wisata yang meliputi daya tarik wisata di atas. Variabel yang digunakan berdasarkan teori sikap oleh Azwar (2010) yaitu komponen kognitif, afektif, dan konatif. Teori yang juga digunakan ialah variabel motivasi yang terdiri dari faktor pendorong dan faktor penarik. Teknik pengumpulan data dilakukan dengan observasi, kuesioner, wawancara, studi kepustakaan, dan dokumentasi. Teknik pengambilan sampel dilakukan dengan purposive sampling. Pengumpulan data dilakukan dengan penyebaran kuesioner terhadap 100 responden. Penelitian ini menggunakan analisis deskriptif kualitatif dengan bantuan skala likert.

\section{HASIL DAN PEMBAHASAN Karakteristik Pramuwisata}

Karakteristik dalam penelitian ini ialah karakteristik pramuwisata berbahasa Korea di Bali yang meliputi karakteristik yang dominan berdasarkan umur yaitu 41-45 tahun sebanyak 32 orang dengan persentase $32 \%$; berdasarkan asal Kabupaten Gianyar sebanyak 53 orang dengan persentase 53\%; berdasarkan status perkawinan, kawin sebanyak 97 orang dengan persentase $97 \%$; berdasarkan pendidikan terakhir, SMA/K sederajat 80 orang dengan persentase $80 \%$; berdasarkan lama menjadi pramuwisata, 6-10 tahun sebanyak 46 orang dengan persentase $46 \%$; berdasarkan apakah guiding menjadi pekerjaan utama, jawaban $\mathrm{Ya}$ dengan 92 orang dengan persentase 92\%; berdasarkan pendapatan rata-rata perbulan yaitu > Rp. 5.000.000 sebanyak 36 orang dengan persentase $36 \%$.

\section{Sikap Pramuwisata Bali Berbahasa Korea terhadap Wisatawan Korea Selatan ke Bali}

Pada variabel sikap pada penelitian ini mendapatkan responden sebanyak 100 responden. Adapun tiga indikator yang dipakai yaitu kognitif, afektif, dan konatif dengan total 4 pernyataan yang memiliki hasil bahwa untuk skor variabel sikap dapat dilihat bahwa pada sub indikator tertinggi pada indikator afektif yaitu "Menurut saya wisatawan Korea sedikit yang berkunjung ke Bali" yang rata-ratanya ialah 4,11 dengan kategori sangat setuju. Selanjutnya dilanjutkan oleh indikator afektif juga dengan sub indikator "Menurut saya Wisatawan Korea banyak yang berkunjung ke Bali” yang memiliki kategori setuju dengan rata-rata 3,57. Selanjutnya indikator konatif dengan satu sub indikator yaitu "Bila tidak ada wisatawan Korea datang, saya akan mencari pekerjaan lain" dengan kategori netral dengan rata-rata 3,27. Selanjutnya Indikator kognitif yakni dengan sub indikator "Saya lebih sering melihat pramuwisata berbahasa lain bekerja daripada guide Korea" memiliki rata-rata 3,13 dengan kategori netral.

Hasil tersebut juga diperkuat dengan adanya wawancara dengan responden yang 
menunjukkan bahwa pramuwisata berbahasa Korea memang lebih sering menemukan pramuwisata berbahasa lain namun tidak terlalu terus menerus secara berkala hal seperti ini terjadi. Selain indikator tersebut, terdapat juga pramuwisata berbahasa Korea yang penulis wawancarai tentang pernyataan di kuesioner mengenai indikator afektif yaitu "Menurut saya wisatawan Korea sedikit yang berkunjung ke Bali" dengan presentase tertinggi pada variable sikap yang masuk ke dalam kategori setuju itu menyatakan bahwa kunjungan wisatawan Korea Selatan ke Bali cukup sedikit dan dalam data statistik oleh BPS Bali menyatakan kunjungan wisatawan Korea Selatan mengalami fluktuasi atau pasang surut tiap tahunnya, namun wisatawan Korea Selatan juga masih menggunakan jasa tour and travel di Bali yaitu pasangan honeymoon, paket wisata honeymoon ini lumayan diminati oleh pasangan dari Korea Selatan, paket ini terdiri dari photo session dengan busana adat Bali, melihat pembuatan kerajinan perak dan kain batik serta berkunjung ke Pura-Pura seperti Pura Tampaksiring, Goa Gajah dan masih banyak lagi aktifitas yang dapat dilakukan oleh wisatawan Korea Selatan di Bali dengan menggunakan jasa tour and travel.

Hasil wawancara dengan responden, menyimpulkan bahwa responden tersebut sudah bekeluarga yang dimana jika terjadinya penurunan jumlah wisatawan Korea Selatan yang berkunjung ke Bali ini akan berdampak buruk ke pada pramuwisata itu sendiri dan keluarganya jika fenomena penurunan jumlah wisatawan ini terjadi secara terus menerus. Maka dari itu dapat disimpulkan bahwa sikap pramuwisata terhadap kunjungan wisatawan Korea Selatan ke Bali ialah sedikit atau mengalami penurunan dan dirasakan juga oleh pramuwisata berbahasa Korea di Bali dan hal ini dapat berdampak negatif karena fenomena ini dapat membuat pramuwisata jarang melakukan kegiatan kepemanduan dibanding saat high season maupun saat terjadinya peningkatan jumlah kunjungan wisatawan Korea Selatan ke Bali.

\section{Motivasi Pramuwisata Bali Berbahasa Korea terhadap Wisatawan Korea Selatan ke Bali}

Pada variabel motivasi ini dibagi menjadi dua indikator yaitu pull factor dan push factor serta memiliki sepuluh pernyataan atau sub indikator yang memiliki hasil bahwa diantara sub indikator di indikator pull factor yang memiliki rata-rata tertinggi yaitu sub indikator "Untuk memenuhi kebutuhan keluarga" dengan rata-rata 4,39 dan memiliki kategori sangat setuju. Selanjutnya sub indikator "Sebuah prestise/kebanggan menjadi seorang guide" dengan kategori sangat setuju dan memiliki rata-rata sebesar 4,31. Sub indikator selanjutnya yaitu "Memang bercitacita menjadi guide dengan persentase sebesar 3,99 dan masuk dikategori setuju. Selanjutnya yaitu dengan sub indikator "Usia sudah melebihi jika melamar dibidang lain" dengan rata-rata sebesar 3,46 dan memiliki kategori setuju. Dan sub indikator yang terendah pada indikator pull factor adalah "Tidak adanya keterampilan lain selain menjadi guide" dengan rata-rata 3,43 dan masuk di kategori setuju. Hal ini menunjukkan bahwa dalam pull factor, motivasi menjadi pramuwisata berbahasa Korea yang dimana jumlah kunjungan wisatawan Korea Selatan yang tidak pasti atau dikatakan tiap tahunnya mengalami kenaikan maupun penurunan, alasan responden menjadi pramuwisata karena untuk pemenuhan kebutuhan keluarga.

Pada indikator push factor atau faktor pendorong dari luar yang memiliki rata-rata tertinggi yaitu sub indikator "Adanya peluang menjadi seorang guide" dengan rata-rata tertinggi yaitu 4,41 dengan kategori sangat setuju. Selanjutnya yaitu sub indikator "Keramahtamahan wisatawan Korea Selatan" yang memiliki rata-rata sebesar 4,23 dengan kategori sangat setuju. Sub inikator berikutnya ialah "Sistem kerja yang bisa disesuaikan" rata-ratanya sebesar 4,18 dengan kategori setuju. Selanjutnya yaitu sub indikator "Suasana kerja yang nyaman" dengan rata-rata sebesar 4,13 dengan kategori setuju dan sub indikator terakhir dan terendah pada indikator push factor yaitu "Pendapatan diterima setiap kali tour" dengan rata-rata sebesar 3,78 dan masuk ke kategori netral.

Hal ini menunjukkan bahwa peluang untuk menjadi pramuwisata sangat lah besar karena lowongan pramuwisata dibuka setiap tahunnya oleh DPD HPI di masing-masing daerah, serta peluang menjadi pramuwisata sangat besar terutama pada saat high season karena tour and travel membutuhkan banyak pramuwisata dan biasanya saat high season, tour and travel mengkontrak beberapa pramuwisata dan pramuwisata tersebut 
mendapatkan gaji pokok tetap setiap bulannya selama masa kontak.

Dari kedua indikator pull factor dan push factor tersebut, pernyataan memenuhi kebutuhan keluarga dan adanya peluang menjadi seorang pramuwisata merupakan yang dominan. Dari data karakteristik berdasarkan status perkawinan, dijabarkan bahwa sebanyak 97\% pramuwisata atau reponden peneliti sudah kawin yang berarti mereka memiliki tanggungan selain dirinya sendiri atau memiliki tanggung jawab untuk memenuhi kebutuhan keluarga yang mengartikan hidupnya sangat bergantung pada pengasilannya menjadi seorang guide namun disisi lain, terdapat beberapa pramuwisata yang memiliki usaha sebagai pedagang maupun memiliki lahan pertanian untuk memenuhi keluarganya, namun sebanyak $92 \%$ responden menjawab pramuwisata sebagai pekerjaan utama yang mana pekerjaan ini sangat diharapkan oleh pramuwisata itu sendiri agar wisatawan Korea Selatan yang menggunakan jasa tour and travel selalu meningkat tiap tahunnya agar pramuwisata tersebut dapat melakukan kegiatan kepemanduan secara terus menerus dan berkala.

Pada push factor dengan pernyataan adanya peluang sebagai pramuwisata, menurut hasil wawancara dengan I Nyoman Nuarta selaku Ketua DPD HPI Bali pada tahun 2017 mengatakan bahwa perekrutan pramuwisata ini dilakukan secara berkala yaitu dilakukan setiap setahun sekali dan dilakukan uji budaya dan uji kompetensi selama 6 hari yang awal pelaksanaanya dimulai dengan uji bahasa sesuai dengan bahasa yang dikuasai oleh masing-masing peserta dan kemudian dilanjutkan dengan diklat. Dalam diklat tersebut semua calon pramuwisata akan mendapatkan pengetahuan tentang kepemanduan dari narasumber-narasumber yang sudah berpengalaman di bidangnya setelah diklat berakhir, akan dilanjutkan dengan uji filtrip atau ujian praktek melakukan kepemanduan dengan bahasa yang dikuasai dan diakhir jika calon pramuwisata lolos maka akan mendapatkan KTPP atau Kartu Tanda Pengenal Pramuwisata atau yang lebih dikenal dengan Lisensi yang dikeluarkan pemerintah setelah mengikuti pelatihan pramuwisata.

Maka dari itu, kesempatan menjadi pramuwisata khusunya di Bali sangatlah luas dan terbuka bagi semua kalangan masyarakat yang membuat perekrutan ini diminati tiap tahunnya, terutama kepada masyarakat yang sudah pensiun atau berumur sudah tua yang ingin bekerja secara fleksibel namun jika bekerja seperti kantoran rata-rata batas umur sudah tidak mencukupi kriteria di berbagai perusahaan.

\section{SIMPULAN DAN SARAN Simpulan}

Berdasarkan hasil dan pembahasan yang telah diuraikan terkait sikap dan motivasi pramuwisata Bali berbahasa Korea terhadap Wisatawan Korea Selatan yang berkunjung ke Bali, maka dapat diambil simpulan bahwa pada variabel sikap meliputi kognitif/perseptual, afektif/emosional, konatif/perilaku. Diantara ketiga indikator tersebut, sub indikator tertinggi pada indikator afektif yaitu kunjungan Wisatawan Korea Selatan sedikit yang datang ke Bali memiliki rata-ratanya ialah 4,11 dengan kategori sangat setuju. Selanjutnya indikator afektif dengan sub indikator kunjungan Wisatawan Korea Selatan datang ke Bali memiliki kategori setuju dengan rata-rata 3,57. Indikator konatif dengan satu sub indikator jika tidak ada wisatawan Korea datang, akan mencari pekerjaan lain masuk kategori netral dengan rata-rata 3,27. Untuk indikator kognitif pramuwisata lebih sering melihat pramuwisata berbahasa lain bekerja daripada guide Korea dengan rata-rata 3,13 masuk kategori netral.

Sedangkan pada variabel motivasi, pramuwisata berbahasa Korea terhadap kunjungan wisatawan Korea Selatan ke Bali dibagi faktor penarik atau pull factor dan faktor pendorong atau push factor. Indikator pull factor memiliki nilai dominan untuk memenuhi kebutuhan keluarga dengan ratarata 4,39, memiliki kategori sangat setuju. Sub indikator yang terendah pada indikator pull factor adalah tidak adanya keterampilan lain selain menjadi guide dengan nilai 3,43 dan masuk kategori setuju. Sedangkan pada indikator push factor atau faktor pendorong memiliki nilai dominan adanya peluang menjadi seorang guide dengan nilai dominan yaitu 4,41 masuk kategori sangat setuju. Sub indikator terakhir dan terendah pada indikator push factor adalah pendapatan diterima setiap kali tour dengan nilai 3,78 masuk kategori netral. Kedua indikator di atas menunjukkan bahwa indikator pull factor, dalam motivasi bertahan pramuwisata terhadap kunjungan 
Wisatawan Korea Selatan yang tiap tahunnya mengalami fluktuasi untuk pemenuhan kebutuhan keluarga. Sedangkan pada push factor adanya peluang menjadi seorang guide tiap tahunnya.

\section{Saran}

Berdasarkan hasil dari pembahasan dalam penelitian ini, maka saran yang dapat direkomendasikan kepada pemerintah sebagai pihak tertinggi diharapkan lebih meningkatkan kemampuan pramuwisata seperti mengadakan pelatihan kepemanduan secara berkala setahun atau lima tahun sekali agar pramuwisata dapat lebih ter-asah kemampuannya. Sedangkan untuk pramuwisata itu sendiri diharapkan dalam melakukan pelayanan untuk mematuhi kode etik sehingga wisatawan merasa puas. Pramuwisata juga diharapkan dapat lebih mengembangkan potensi dan keterampilan dengan selalu mengasah kemampuan serta mengembangkan wawasan. Sedangkan untuk praktisi maupun akademisi dengan adanya penelitian ini akan menambah referensi penelitian selanjutnya dan diharapkan dapat melibatkan stakeholder kepariwisataan lainnya serta pihak-pihak yang terkait sebagai acuan penyusunan penelitian selanjutnya. 
Jurnal IPTA

p-ISSN: $2338-8633$

Vol. 8 No. 1,2020

\section{Kepustakaan}

Anonim. Undang Undang tentang Kepariwisataan, UU No. 10 Tahun 2009. Jakarta: Direktorat Jenderal Hukum dan HAM.

Azwar, Saifudin. 2010. Sikap Manusia Teori dan Pengukurannya. Yogyakarta: Pustaka Pelajar.

"Banyaknya Wisatawan Mancanegara yang Datang Langsung ke Bali Menurut Kebangsaan, 2014-2018", (2 September, 2019), (bali.bps.go.id), Tersedia: https://bali.bps.go.id/statictable/2018/02 /09/27/jumlah-wisatawan-mancanegarayang-datang-langsung-ke-bali-menurutkebangsaan-2013-2017.html (diakses: 5 Mei 2019)

Pitana, \& Diarta, 2003. Pengantar Ilmu Pariwisata. Yogyakarta.

Suwena, Widyatmaja, 2010. Pengetahuan Dasar Ilmu Pariwisata. Denpasar:Udayana University Press. 